\title{
JUDICIAL REVIEW UNDER THE CLEAN AIIR AMENDMENTS
}

In enacting the Clean Air Amendments of $1970,{ }^{1}$ Congress sought to remedy the lack of uniform national air quality standards, the paucity of state-federal coordination, and above all, the absence of meaningful federal enforcement authority which had plagued previous federal attempts to achieve air pollution control. ${ }^{2}$ Although the original dates for establishing and attaining national air quality standards under the

THE FOLLOWING CITATIONS WILL BE USED IN THIS NOTE:

Clean Air Amendments of 1970, Pub. L. No. 91-604, 84 Stat. 1676 (codified at 42 U.S.C. $\S \S 1857$ et seq. (1970)) [hereinafter cited as Amendments];

H.R. Rep. No. 91-1146, 91st Cong., 2d Sess, (1970) [hereinafter cited as House REPORT];

S. Rep. No. 91-1196, 91st Cong., 2d Sess. (1970) thereinafter cited as Senate REPORT];

K. Davis, Administrative LaW Treatise (1958) [hereinafter cited as Davis];

L. JAFFE, JUdictal. Control of Administrative Action (1965) [hereinafter cited as J $\mathrm{AFFE}$.

1. Amendments.

2. The earliest federal effort to regulate air pollution was the enactment of the Air Pollution Control Act, ch. 360, 69 Stat. 322 (1955), which was designed to pronote research and to support local abatement efforts. Subsequent legislation directed the surgeon general to investigate the effect of motor vehicle enissions on health. Act of June 8, 1960, Pub. L. No. 86-493, 74 Stat. 162. In 1963 the federal government was authorized to increase its support for research and local control, and to exercise imited enforcenent authority over some forms of interstate pollution. Clean Air Act, Pub. L. No. 88-206, 77 Stat. 392 (1963). The Air Quality Act of 1967, Pub. L. No. 90-148, 81 Stat. 485, brought about some expansion of federal enforcement authority, but left to the states the critical matters of setting air quality standards and attainment schedules. For a review and analysis of legislation antecedent to the 1970 Amendments, see Train v. Natural Resources Defense Council, 421 U.S. 60, 63-65 (1975); Greco, The Clean Air Amendments of 1970: Better Automotive Ideas from Congress, 12 B.C. IND. \& COM. L. REv. 571, 581, 589 (1971); O'Fallon, Deficiencies in the Air Quality Act of 1967, 33 LAw \& Contemar. PRoB. 275 (1968); Counment, Variance Procedures Under the Clean Air Act: The Need for Flexibility, 15 WM. \& MARY L. REv. 324, 324 n.1 (1973).

Both houses of Congress put repeated einphasis on the inadequacies of previous legislation in justifying the Amendments:

Air pollution continues to be a threat to the health and well-being of the American people. While a start has been made in controlling air pollution since the enactment of the Air Quality Act of 1967, progress has been regrettably slow. This has been due to a number of factors: (1) cumbersome and time-consuming procedures called for under the 1967 act ... [references to technological problems] . . . and (6) last, but not least, failure on the part of the National Air Pollution Control Administratiou to demonstrate sufficient aggressiveness in implementing present law. HOUSE REPORT 5.

See also SENATE REPORT 3. 
Amendments have passed, ${ }^{3}$ many states are still in the process of gaining necessary federal approval for details of their air quality implementation plans, ${ }^{4}$ and revisions of plans already approved are constantly being proposed. 5 Therefore, the obligations of industries subject to the federally supervised state regulation mandated by the Amendinents have not yet been fully defined, and affected industries have a continuing interest in obtaining adequate judicial review of administrative determinations made pursuant to the Amendments.

As with all forms of federal regulation, administrative action under the Amendments which has an impact of substantial finality on the parties being regulated is subject to a presumption of judicial reviewability. ${ }^{6}$ The statute itself specifies procedures to be followed in a number of situations where review is clearly appropriate. ${ }^{7}$ As the developing case law demonstrates, lowever, Congress did not begin to envision the inultitude of legal and factual circumstances in which soine form of judicial review might reasonably be demanded. Nor have the courts confronted with these demands been able to arrive at consistent answers to the questions of when statutory or extra-statutory review should be permitted, what forms it should take, and at what stages of the review proceedings particular kinds of issues should be raised. ${ }^{8}$

3. The target date for achieving the national primary standards was May, 1975. Although this date does not appear explicitly in the Amendments, it can be calculated from the time limitations on the various procedures which are mandated. See Comment, Variance Procedures Under the Clean Air Act, supra note 2, at 327 n.14. See notes 915 infra and accompanying text for a discussion of the relevant statutory provisions.

4. See, e.g., 5 BNA ENVIRONMENT REP. $452-53$ (1974) (summarizing a number of state regulations belatedly issued during 1974). Extensions of statutory deadlines, Environmental Protection Agency (EPA) dissatisfaction with original state submissions, protracted litigation, and inevitable bureaucratic delay have all contributed to the failure to meet the Amendments' goals on schedule. See Air: Turning the Corner, NAT'L WILDLIFE 21 (Feb.-Mar. 1976).

5. Eacli state implementation plan is required to have a workable revision provision. Amendments $\$ 110(a)(2)(H), 42$ U.S.C. $\$ 1857 c-5(a)(2)(H)(1970)$. See also Amendments $\$ 110$ (a) (3), 42 U.S.C.A. $\$ 1857$ c-5(a)(3) (Supp. 1976). Additionally, section 111, dealing with new sources, incorporates the general procedure of section 110 for the developinent of state standards applicable to these new sources and the federal approval of these new standards. Amendments $\S 111(d), 42$ U.S.C. $₹ 1857$ c-6(d) (Supp. III, 1973). The problems arising in the application of section 111 are discussed in Oljato Chapter of the Navajo Tribe v. Train, 515 F.2d 654 (D.C. Cir. 1975).

6. See Abbott Laboratories v. Gardner, 387 U.S. 136 (1967); Gardner v. Toilet Goods Ass'n, 387 U.S. 167 (1967). See generally Note, Statutory Preclusion of Judicial Review Under the Administrative Procedure Act, 1976 DukE L.J. $431 ; 5$ U.S.C. $\S \S 702$, 704 (1970). In enacting the Amendments, Congress evinced specific concern for the implications of the APA and recent cases construing it. SENATE REPORT 40-41.

7. Amendments $\S 304,42$ U.S.C. $\$ 1857 \mathrm{~h}-2$ (1970); Amendments $\S 307(\mathrm{~b}), 42$ U.S.C.A. \$ 1857h-5(b) (Supp. 1976). These provisions governing judicial review are discussed at notes 20-23 infra and accompanying text.

8. See, e.g., West Penn Power Co. v. Train, 522 F.2d 302, 308 n.25 (3d Cir. 1975); 
The purpose of this Note is to review the statutory scheme as presently construed, to analyze critically the approaches taken to the judicial review problem in the leading recent cases, and to suggest an alternative framework for judicial review under the Amendments with a view toward reducing the confusion so frequently expressed and reflected by courts and litigants.

\section{The Statutory Origins of the Judicial Review Problem}

\section{The Statutory Scheme}

The operation of the Clean Air Amendments involves three principal phases: the setting of national air quality standards, ${ }^{9}$ the development, adoption, and federal approval of state plans to implement those national standards, ${ }^{10}$ and the enforcement of the state plans to ensure that the national standards are achieved and maintained. ${ }^{11}$

While the details of many state plans have not yet been made final, the first two phases are for the most part complete. The Amendments required the Administrator of the United States Environmental Protection Agency (EPA) to promulgate, shortly after enactment, national primary and secondary air quality standards for all pollutants which had been identified as threats to public health or welfare. ${ }^{12}$ After pronulgation of the national standards, each state was to subimit to the EPA a more specific plan for implementing these standards. ${ }^{13}$ EPA approval was to be given to a state plan if a set of enumerated criteria were niet. ${ }^{14}$

Duquesne Light Co. v. EPA, 481 F.2d 1 (3d Cir. 1973), modified, 522 F.2d 1186 (3d Cir. 1975); Getty Oil Co. v. Ruckelshaus, 467 F.2d 349 (3d Cir. 1972), cert. denied, 409 U.S. 1125 (1973).

9. Amendments $\S 109,42$ U.S.C. $\S 1857 \mathrm{c}-4$ (1970).

10. Amendments $\$ 110,42$ U.S.C.A. $\$ 1857 c-5$ (Supp. 1976).

11. Amendments $\S 113,42$ U.S.C.A. $\$ 1857 c-8$ (Supp. 1976). For concise reviews of the statutory scheme, see Train v. Natural Resources Defense Council, 421 U.S. 60, 64-68 (1975); Natural Resources Defense Council v. EPA, 483 F.2d 690, $691-92$ (8th Cir. 1973).

12. Primary standards are those which the EPA Administrator determines "are requisite to protect the public health." Amendments $\$ 109(\mathrm{~b})(1), 42$ U.S.C. $\$ 1857 \mathrm{c}$ $4(b)$ (1) (1970). Secondary standards are those necessary "to protect the public welfare from any known or anticipated adverse effects" of air pollution. Amendments \& 109 (b) (2), 42 U.S.C. $\$ 1857 c-4$ (b) (2) (1970). The standards are set out in 40 C.F.R. \$§ $50.1-.11$ (1973).

13. Amendments $\S 110(a), 42$ U.S.C.A. $\S 1857$ c-5(a) (Supp. 1976). The plans were to provide for the attainment of the national primary standard within three years, and for attainment of the national secondary standard within "a reasonable time."

14. Amendments $\S \S 110(\mathrm{a})(2)(\mathrm{A})-(\mathrm{H}), 42$ U.S.C. $\$ \S 1857 \mathrm{c}-5(\mathrm{a})(2)(\mathrm{A})-(\mathrm{H})$ (1970). The criteria include the presence of a specific program adequate to ensure timely attainment of the national standards, sufficient funding, personnel, facilities, and 
Such approval is also required before a state can effectively revise its plan: ${ }^{15}$

Enforceinent under the Amendments is a joint state-federal effort. Primary responsibility for enforcement of the implementation plans rests with the states. ${ }^{16}$ The enforcennent provision of the Amendments,

authority for monitoring and enforcement, and a workable provision for necessary revisions.

15. Amendments $\$ 110$ (a)(3), 42 U.S.C.A. $\$ 1857 c-5(a)(3)$ (Supp. 1976). Section 110 provides further for the extension of submission deadlines, Amendments $\&$ 110 (b), 42 U.S.C. $\$ 1857 \mathrm{c}-5$ (b) (1970), for the promulgation of implementation plans by EPA in default of state action, Amendments $\$ 110(\mathrm{c}), 42$ U.S.C.A. $\$ 1857 \mathrm{c}-5(\mathrm{c})$ (Supp. 1976), and, under extraordinary circumstances, for the extension of the national deadline with respect to an entire state, Amendments $\$ 110(\mathrm{e}), 42$ U.S.C. $\$ 1857 \mathrm{c}-5(\mathrm{e})$ (1970), or to a source or class of sources within a state, Amendments $\S 110(f), 42$ U.S.C. $\$ 1857 c-5(f)(1970)$.

The question of when a state is required to use the section $110(f)$ procedure to modify its implementation plan was decided in Train v. Natural Resources Defense Council, 421 U.S. 60 (1975). The Fifth Circuit had sustained NRDC's argument that section $110(f)$ is the sole means by which a state may revise its plan so as to postpone its application to a particular pollution source. Natural Resources Defense Council v. EPA, 489 F.2d 390 (5th Cir. 1974). In similar challenges to EPA approval of the variance procedures of state plans, the First, Second, and Eighth Circuits had held that a state, "as a necessary adjunct to the statutory scheme," had an inherent, extra-statutory right to revise its plan without recourse to section $110(f)$ at any time before the state was scheduled to attain the national air quality standard. See Natural Resources Defense Council v. EPA, 478 F.2d 875, 887 (1st Cir. 1973). After the scheduled attainment dates, these courts held, the state could revise its plan only if the cumbersome procedure of section 110(f) were followed. See Natural Resources Defense Council v. EPA, 494 F.2d 519 (2d Cir. 1974); Natural Resources Defense Council v. EPA, 483 F.2d 690 (8th Cir. 1973); Natural Resources Defense Council v. EPA, 478 F.2d 875 (1st Cir. 1973). The Ninth Cirouit rejected the pre- and post-attainment date distinction but followed the First Circuit in finding an inherent power for a state to make such revisions in its plan as would not interfere with attainment or maintenance of national standards. Natural Resources Defense Council v. EPA, 507 F.2d 905, 912 (9th Cir. 1974). The Supreine Court adopted the simple expedient of reading the statute as it was written, holding that section $110(a)(3)$ governs the federal approval of revisions which do not compromise national standards (i.e. those revisions which meet the criteria specified in section $110(a)(2)(A)-(H))$. The Court found that section $110(f)$ "was intended merely as a method of escape from the mandatory deadlines," and that its procedure is therefore appropriate only for the approval of variances or revisions threatening the national standards. 421 U.S. at 84. Any attempt to distinguish "revision" from "postponement" on the basis of specificity was rejected as "specious." Id. at 97-98. See generally Hardy, Train v. Natural Resources Defense Council: The Genesis of a New Era of Federal-State Relationships in Air Pollution Control, 24 Clev. ST. L. Rev. 397 (1975).

16. See Train v. Natural Resources Defense Council, 421 U.S. 60, 79 (1975); SENATE REPORT 21. Note the requirement of section $110(a)(2)(f)$ that each state have adequate authority to enforce its plan. For an example of the complexities inherent in joimt state-federal enforcement, see Duquesne Light Co. v, EPA, 481 F.2d 1 (3d Cir. 1973), modified, 522 F.2d 1186 (3d Cir. 1975). See generally Luneburg, Federal-State 
however, imposes an independent duty on the EPA Administrator to notify any person he believes to be acting in violation of an approved and currently applicable state implementation plan. ${ }^{17}$ If sucl violation continues for more than thirty days, the Administrator "may" either intiate a civil action in a United States district court to compel compliance with the plan, or issue an administrative order directing compliance which is itself enforceable in a civil action. ${ }^{18}$ The Amendments prescribe substantial penalties for knowingly violating a compliance order or ignoring a violation notice issued by the EPA. ${ }^{19}$

An enforcement suit will necessarily provide an opportunity for judicial review of the administrative actions on which the suit is based. Additionally, the Amendments provide explicitly for two other forms of judicial review. First, EPA action on a proposed state implementation plan or revision is immediately reviewable in the court of appeals of "the appropriate circuit."20 Consideration in enforcement proceedings of

Interaction Under the Clean Air Amendments of 1970, 14 B.C. IND. \& CoM. L. REv. 637 (1973).

17. (a) (1) Whenover, on the basis of any information available to him, the Administrator finds that any person is in violation of any requirement of an applicable implementation plan, the Adıninistrator shall notify the person in violation of the plan and the State in which the plan applies of such finding. If such violation extends beyond the 30th day after the date of the Administrar tor's notification, the Administrator may issue an order requiring such person to comply with the requirenents of such plan or he may bring a civil action in accordance with subsection (b) of this section. Amendments $\S 113(a)(1)$, 42 U.S.C. $\$ 1857 c-8(a)(1)$ (1970).

18. Id.; Amendments $\S 113($ b), 42 U.S.C.A. 1857c-8(b) (Supp. 1976) (authorizing the EPA Administrator to commence a civil action to either enforce his compliance order or to enjoin violations of a state plan). It is unclear whether the Administrator is required to take either of these two steps, or whether action beyond the issuance of a violation notice is entirely discretionary. See notes 112-14 infra and accompanying text.

19. Persons who knowingly violate orders issued pursuant to section 113 are subject to a fine of not more than $\$ 25,000$ per day of violation, or imprisonment for not more than one year, or both. Amendments $\S 113(\mathrm{c})(1), 42$ U.S.C.A. $\S 1857 \mathrm{c}-8(\mathrm{c})(1)$ (Supp. 1976).

20. Amendments $\$ 307$ (b)(1), 42 U.S.C.A. $\S 1857 \mathrm{~h}-5$ (b) (1) (Supp. 1976), provides in pertinent part:

A petition for roview of the Administrator's action in approving or promulgating any implementation plan ... may be filed only in the United States Court of Appeals for the appropriate circuit. Any such petition shall be filed within 30 days from the date of such promulgation, approval, or action, or after such date if such petition is based solely on grounds arising after such 30 th day.

EPA action in promulgating national standards is reviewable in the court of appeals for the District of Columbia Circuit. Id. Whilo the statute does permit a petition for review to bo filed after the thirty-day limitation period when it is based on grounds arising after that dite, it is often difficult to ascertain the point at which such grounds have in fact arisen. This difficulty is illustrated by Union Elec. Co. v. EPA, 515 F.2d 206 (8th Cir. 1975), and Oljato Chapter of the Navajo Tribe v. Train, 515 F.2d 654 (D.C. Cir, 1975). 
matters which could have been raised previously in such a review action is specifically foreclosed. ${ }^{21}$ Second, a unique "citizen suit" provision grants jurisdiction to federal district courts to hear suits brought by "any person" against alleged violators of any state or federal standard adopted pursuant to the Amendments, or against the EPA for alleged failure to perform nondiscretionary duties. ${ }^{22}$ The main purpose of this provision apparently is to provide a meaningful check on EPA laxity in enforcement. ${ }^{23}$

\section{The Problem}

Despite the apparent comprehensiveness of the Amendments' review provisions, the courts construing these provisions have been unable to arrive at a consistent answer to the question of when affected industries should raise particular types of objections to state and federal action in developmg, approving, revising, and enforcing implementation plans. ${ }^{24}$ Thus, while these industries face foreclosure of objections not raised at the proper time and in the appropriate tribunal, ${ }^{25}$ they are without definitive judicial guidelines in timing the exercise of their statutory right to judicial review.

21. "Action of the Administrator with respect to which review could have been obtained [in an initial review proceeding] shall not be subject to judicial review in civil or criminal proceedings for enforcement." Amendments \& 307(b)(2), 42 U.S.C. \& $1857 \mathrm{~h}-5$ (b)(2) (1970).

22. (a) Establishment of right to bring suit.

Except as provided in subsection (b) of this section, any person may commence a civil action on his own behalf-

- ...

(2) against the Administrator where there is alleged a failure of the Administrator to perform any act or duty under this chapter which is not discretionary with the Administrator.

The district courts shall have jurisdiction, without regard to the amount in controversy or the citizenship of the parties, to enforce such an emission standard or limitation, or such an order, or to order the Administrator to peform such act or duty, as the case may be.

(b) Notice.

No action may be commenced-

(2) under subsection (a) (2) of this section prior to 60 days after the plaintiff has given notice of such action to the Administrator. Amendinents $\$ 304$, 42 U.S.C. \$ $1857 \mathrm{~h}-2$ (1970).

See SENATE REPORT 38 (discussing the uniqueness of this provision).

23. See Senste Report 3. The topic of judicial review under the Amendments has been generally reviewed in Leventhal, Environmental Decisionmaking and the Role of the Courts, 122 U. PA. L. Rev. 509 (1974); Comment, Coordinating the EPA, NEPA, and the Clean Air Act, 52 TEx. L. REv. 527, 550-56 (1974); Note, Reviewability: Statutory Limitations on the Availability of Judicial Review, 1973 DuKe L.J. 253.

24. See cases cited at note 8 supra.

25. See note 21 supra and accompanying text. 
At the heart of the problem is the question of what issues must be raised on direct review of EPA approval of a state implementation plan or revision. On the one hand, several cases have suggested that any remotely foreseeable present or future objection arising in relation to a state plan must be raised at the time of EPA approval. ${ }^{28}$ On the other hand, it recently has been held that only general objections to the overall policy of a state plan are reviewable at this time. ${ }^{27}$

Obviously, the safest course for the affected industry to pursue is to raise all possible objections on imitial review of EPA approval. Encouraging this position, however, is undesirable for at least two reasons. First, as a practical matter, the full implications of an objection which is foreseeable only in a very general way may not yet be discernible at the time of plan approval, resulting in an inadequate discussion and resolution of the issues involved. ${ }^{28}$ Second, even if enough information is available to allow the objection to be fully developed, the delay imevitable in a judicial determination of complex technological questions may defeat Congress's clearly expressed intent to expedite attainment of the national standards. ${ }^{29}$ An arguable interpretation of the Amendments' legislative history is that no tactic which will unduly delay the preattainment procedure is to be tolerated, and that complex objections to a plan which would have a delaying effect are to be brought not before the courts, but before Congress itself as amendment proposals. ${ }^{30}$

If, alternatively, the industry is not permitted to raise all conceivable objections to an implementation plan at the time of approval, the current imconsistency in judicial interpretation of the Amendments may subject it to the risk of having its imterests adversely affected without adequate review of its objections. Besides initial review in a federal court of appeals, the Amendments provide an industry subject to a plan

26. See, e.g., St. Joe Mineral Corp. v. EPA, 508 F.2d 743, 747-49 (3d Cir. 1975); Getty Oil Co. v. Ruckelshaus, 467 F.2d 349, 358 (3d Cir. 1972), cert. denied, 409 U.S. 1125 (1973); West Penn Power Co. v. Train, 378 F. Supp. 941, 945-47 (W.D. Pa. 1974), aff'd on other grounds, 522 F.2d 302, 309 (3d Cir. 1975) (the trial and appellate courts presenting the two conflicting views on initial reviewability).

27. West Penn Power Co. v. Train, 522 F.2d 302, 309 (3d Cir. 1975).

28. For exanple, the ultimate technological implications of a particular plan provision are likely to be only dimly foreseeable at the time an affected industry becomes subject to the plan. See note 61 infra and cases cited therein for a discussion of other aspects of the problem.

29. See Senate Report 2-3; 116 Cong. Rec. 32,900-05 (1970) (remarks of Senator Muskie).

30. See 116 CONG. REc. 32,905 (1970) (remarks of Senator Muskie). Senator Muskie suggested that objections requiring complex substantive determinations were not proper subjects for judicial review, but rather should be brought to Congress's attention as possible grounds for revision of the Amendments themselves. 
to which it objects with three courses of relief; but none of these guarantees meaningful review.

The first option is to rely on review of the objectionable aspects of a state plan by the courts or the appropriate administrative agency of the state concerned. ${ }^{31}$ The implementation plans or administrative procedure statutes of most states provide for the granting of a stay of enforcement during the pendency of such review. ${ }^{32}$ Under the Amendments, however, activity im violation of an approved plan is subject to federal sanctions, regardless of any state determinations. ${ }^{33}$ Moreover, any ultimate federal penalties will be calculated from the date of the violation notice which the EPA Administrator is required to issue to any person he believes to be acting in contravention of the most recently approved version of a state plan. ${ }^{34}$ An alleged polluter without absolute confidence in the correctness of his position is thus deterred from relying on available state remedies by the knowledge that he may be heavily penalized for his activities during the time required to complete the state process.

The second possible course of relief is the citizen suit provision. ${ }^{35}$ This provision, however, appears by its terms and purpose to be inapplicable to the situation of an affected industry seeking judicial review of a state plan or its application. ${ }^{38}$

A third option is to do nothing and await the opportunity to raise objections not suitable for imitial court of appeals review as a defense in a statutory enforcement action brought by the EPA. ${ }^{37}$ Here again, an affected industry faces the accrual of penalties from the date of the issuance of a violation notice. Following the required issuance of the notice, the form and timing of further enforcement proceedings are at

31. An example is the procedure for the granting of variances and subsequent review set forth in 25 PA. CODE $\$ 141$; PA. STAT. ANN. tit. 35, $\$ \S 4004(4)$ ) 4013.5 (Supp. 1975); id. tit. $71 \S 1710.41$.

32. See, e.g., $25 \mathrm{PA}$. CODE $\$ 141.5$.

33. In other words, a state ruling apparently has no binding effect on federal officials, and thus a party found in comphance with the applicable standards by the state may nonetheless be subject to federal sanction. See notes 83-86 infra and accompanying text.

34. See notes 16-19 supra and accompanying text. Any person knowingly refusing to comply with a violation notice for more than thirty days after its issuance becomes subject to a fine of up to $\$ 25,000$ per day or imprisonment for one year or both. Amendments $\$ 113$ (c)(1), 42 U.S.C.A. $\$ 1857$ c-8(c)(1) (Supp. 1976).

35. Amendments $\S 304,42$ U.S.C. $\$ 1857 \mathrm{~h}-2$ (1970) (quoted in part in note 22 supra).

36. See note 23 supra and accompanying text.

37. See note 18 supra and accompanying text. The explicit prohibition against raising matters which should have been reviewed initially in the conrt of appeals suggests that issues not specifically precluded can be asserted as defenses in enforcement actions. 
the discretion of the EPA..$^{88}$ To continue an allegedly unlawful activity in the expectation of having objections to a state plan heard in an enforcement proceeding is therefore to cede to the EPA's discretion any control over the scope of the sanctions which may ultimately be imposed.

Thus, in spite of the presence of three distinct avenues of review, it may be extremely difficult-as well as risky-to obtain adequate judicial review of administrative action under the Amendments. In response to this apparent lack of adequate statutory remedy, some industries have turned to a fourth, extra-statutory form of review to obtain relief. ${ }^{30}$ Specifically, an industry which is unable to have its objections fully heard in an initial court of appeals proceeding and afraid of the consequences of delay may seek extra-statutory federal judicial intervention at some stage between plan approval and enforcement. For instance, it may be desirable for the industry to obtain judicial review at the time of issuance of a compliance order by the EPA. As will be seen, however, difficulty and uncertainty have plagued these efforts to proceed in the absence of specific statutory authorization and guidelines.

\section{The Problem Exemplified: The West Penn Case}

The problems an industry may face in obtaining adequate judicial review under the Clean Air Amendinents are well illustrated by the recent case of West Penn Power Co. v. Train. ${ }^{40}$ Since the plaintiff's demand in this case was for extra-statutory review of EPA and state action under the Amendments, the Third Circuit was compelled to address itself to the general issue of meaningful judicial review of such administrative action. The difficulties experienced by the West Penn court in reaching a convincingly reasoned resolution of the dispute before it thus provide an excellent vehicle for further examination of the issue and its implications.

As part of its plan inplementing the national air quality standards, Pennsylvania adopted standards limiting particulate and sulphur compound emissions from stationary sources which directly affected a generating plant owned by the West Penn Power Company. The implementation plan was subsequently approved by the EPA.41 Instead of

38. See notes 17-19 supra and accompanying text.

39. See, e.g., West Penn Power Co. v. Train, 522 F.2d 302 (3d Cir. 1975); Getty Oil Co, v. Ruckelshaus, 467 F.2d 349 (3d Cir. 1972), cert. denied, 409 U.S. 1125 (1973).

40. 522 F.2d 302 (3d Cir. 1975).

41. Pennsylvania adopted the implementation plan in January, 1972. See 25 PA. CODE $\$ \S 121-41$. The particulate and sulphur componnd emission regulations relevant to 
seeking review of this approval in a federal court of appeals, West Penn petitioned the state for a statutory variance froin the state plan. ${ }^{42}$ While the variance application was pending, the EPA Administrator issued a notice to West Penn that the generating plant was operating in violation of the Pennsylvania implementation plan. ${ }^{43}$ The state subsequently granted West Penn a partial variance, approving a temporary exception to the sulphur compound emission standards, but rejecting the tall stack scheme proposed by West Penn for future compliance and ordering the coinpany to begin installation of a "stack scrubber." 44 This temporary variance was never approved by the EPA. ${ }^{45}$

West Penn then filed suit in federal district court seeking to enjoin the EPA froin acting.on its violation notice, claiming it was not presently in violation of the state implementation plan, and asking for a declaratory judginent that its tail stack scheme was satisfactory for future compliance. ${ }^{48}$ The court disnnissed the complaint for lack of subject matter jurisdiction, ${ }^{47}$ and its decision was affirmed on appeal by

this case are contained in 25 PA. CODE $\$ 123$. The plan was approved by EPA on May 31, 1972. 37 Fed. Reg. 10889 (1972).

42. See generally 25 PA. CODE \$ 141; PA. Stat. ANN. tit. 35, \$ 4013.5 (Supp. 1975). West Penn's application with the state was filed on September 15, 1972, and amended on June 7, 1973. West Penn proposed to reduce sulplur componnd pollution by burning low-sulplur fuel and building a tall stack to disperse pollutants higher in the atmosphere. $522 \mathrm{~F} .2 \mathrm{~d}$ at $305 \mathrm{nn} .5 \& 6$.

43. The order was issued pursuant to Amendments $\S 113$ (a) (1), 42 U.S.C. $\S 1857 \mathrm{c}$ 8 (a) (1) (1970) (quoted in note 17 supra).

44. The state's ruling was issued in Septeinber of 1973 pursuant to Pa. Stat. ANN. tit. 35, §§ 4004(4), 4013.5 (Supp. 1975). West Penn appealed this initial ruling by the Department of Environmental Resources to the Pennsylvania Environmental Hearing Board. See id. tit. 71, § 1710.41. This appeal had not been resolved at the time of the decision in West Penn. 522 F.2d at 305-06 \& n.11.

On the problems of sulphur compound pollution and the use of scrubbers to combat it, see Counct on ENvIRONMENTal QUalitx, FIFTH ANNual Report 118-24 (1974); COUNCIL ON ENYIRONMENTAI QUAITTY, FOURTH ANNUAL REPORT 161-63 (1973).

45. A state variance or revision is ineffective without EPA approval. See note 15 supra and accompanying text.

46. West Penn Power Co. v. Train, 378 F. Supp. 941 (W.D. Pa. 1974), aff'd, 522 F.2d 302 (3d Cir. 1975). The suit was filed in Deceinber of 1973. Named as defendants were EPA Administrator Russell Train, the Secretary of the Pennsylvania Department of Environmental Resources, and the Department itself.

47. 378 F. Supp. at 944-46. West Penn had claimed federal court jurisdiction on the basis of the citizen suit provision of the Amendments, Amendments $\$ 304,42$ U.S.C. $\$$ $1857 \mathrm{~h}-2$ (1970), the judicial review provisions of the Adininistrative Procedure Act, 5 U.S.C. $\$ \S 701-06$ (1970), the Declaratory Judgment Act, 28 U.S.C. \$§ 2201-02 (1970), and the commerce-related federal question statute, 28 U.S.C. $\$ 1337$ (1970). With respect to Train, the court fonnd that West Penn had failed to give him the sixty-day notice required by the citizen suit provision, and that neither the APA, the Declaratory Judgment Act, nor the commerce-related federal question statute constituted a sufficient affirmative grant of jurisdiction to hear a matter not otherwise within its competence. 
the Third Circuit.48 Although admittedly confused by West Penn's definition of the issues, ${ }^{49}$ the appellate court discerned and answered three basic questions.

First, the court rejected the argument that both West Penn's claim that it was not in violation of the Pennsylvania plan and its assertion that a tall stack plan would ensure future compliance should have been raised on direct review of EPA's approval of the Pemisylvania implementation plan. ${ }^{50}$ It adopted the test that suitability for imitial court of appeals review be determined according to whether the objection was to the general nature of the plan or to the details of its application. Since West Pemis claims were highly specific in nature and not challenges to the plan itself, the company was not precluded from raising them at a later time by its failure to raise them at the time of plan approval. ${ }^{51}$

Next, the court addressed the question of whether there was any jurisdictional basis for entertaining the suit. Rejecting West Perm's argument that the Administrative Procedure Act conferred jurisdiction,

In any event, the court concluded, the initial review provision of the Amendments precluded its consideration of these questions since the administrative action complained of was taken in accordance with the Pennsylvania implementation plan, and West Penn therefore should have objected to the plan itself at the time of its promulgation.

The district court relied on Getty Oil Co. v. Ruckelshaus, 467 F.2d 349 (3d Cir. 1972), cert. denied, 409 U.S. 1125 (1973), in holding that the relative specificity of the objection to the plan is immaterial under the initial review provision. $378 \mathrm{~F}$. Supp. at 945. Getty had failed to file a timely objection to the Delaware implemeutation plan in the court of appeals. The company later sought district court review of the application of a low-sulphur fuel regulation which, although stated in general terms, was worded in such detail as to affect only Getty's facility. Getty argued that it accepted the plan generally, and that its objection to the specific regulation was not the sort of challenge envisioned by section 307(b). The court rejected this distinction. $467 \mathrm{~F} .2 \mathrm{~d}$ at 355-56.

The district court in West Penn rejected the complaint against the Department of Environmental Resources and its Secretary for lack of jurisdiction, noting also the possibility of eleventh amendment difficulties. $378 \mathrm{~F}$. Supp. at 947 . It further suggested that any relief it might provide with respect to the state defendants would be futile, since any action they took in revising the Pennsylvania plan or granting variances would be ineffective without EPA approval. 1d. at 947-48.

48. West Penn Power Co. v. Train, 522 F.2d 302 (3d Cir. 1975). West Penn did not challenge the lower court's rulings on the lack of jurisdiction under the Declaratory Judginent Act and the commerce-related federal question statute.

49. See $\$ 22$ F.2d at 308 n.25. Beyond alleging permissibile alternative arguments under FeD. R. Crv. P. 8(a), the court felt that West Penn's brief made serial arguments based on mutually exclusive premises.

50. The court reasoned that "[t]he plan prescribes certain air quality standards . . . not specific means of attaining those standards." 522 F.2d at 309 .

51. By way of illustration, the court distinguished its earlier holding in Getty Oil Co. v. Ruckelshaus, 467 F.2d 349 (3d Cir. 1972), cert. denied, 409 U.S. 1125 (1973), as a case involving a challenge to the state regulations themselves and not to the specific application of those regulations. 522 F.2d at $309 \mathrm{n.28}$. This aspect of the holding is criticized at notes 66-69 infra and accompauying text. 
the court affirmed the lower court's dismissal. ${ }^{52}$ Alternatively, the court stated, even if there were a jurisdictional basis for the suit, the administrative action involved would still not be reviewable because it lacked finality and was "committed to agency discretion by law."53

Finally, the court rejected West Penn's claim that due process required some present judicial review of the administrative action in question, finding that two separate procedures assured the company of its constitutional right to a meaningful hearing at a meaningful time. $^{54}$ To begin with, West Penn had its pending state administrative and judicial review, which nnight ultimately have led to a revision of the state plan in its favor. ${ }^{55}$ Furthermore, the court noted, the EPA

52. 522 F.2d at 309-10. There has been an extensive debate in the literature over the question of whether the APA confers jurisdiction on the federal district courts. See notes 98-100 infra and accoinpanying text.

53. 5 U.S.C. $\$ 701(a)(2)$ (1970). Judicial review under the APA is governed by sections 701 through 706. Id. $\$ \$ 701-06$. The general statutory presumption is that "[a] person suffering legal wrong because of agency action, or adversely affected or aggrieved by agency action within the meaning of a relevant statute, is entitled to judicial review thereof." Id. $\$ 702$. The principal exceptions to this presumption are situations where "statutes preclude judicial review" or "agency action is committed to agency discretion by law." Id. \$ 701(a). See generally Port of Boston Marine Terminal Ass'n v. Rederiaktiebolaget Transatlantic, 400 U.S. 62, 70-71 (1970); 4 DAvis $\$ 28.01$-.08; JAfFe 372; Note, Statutory Preclusion of Judicial Review, supra note 6 . Only final agency action is reviewable. 5 U.S.C. $\$ 704$ (1970); see Abbott Laboratories v. Gardner, 387 U.S. 136, 149 (1967); Toilet Goods Ass'n v. Gardner, 387 U.S. 158, 16066 (1967). The reviewing court is einpowered to compel agency action unlawfully withheld or delayed, and to set aside agency action which is arbitrary, unconstitutional, in excess of the agency's statutory authority, or not carried out in accordance with proper procedural safeguards. 5 U.S.C. $\$ 706$ (1970); see Citizens to Preserve Overton Park, Inc. v. Volpe, 401 U.S. 402, 415 (1970).

For an overview of APA judicial review, see 4 DAvIS $\$ 28$; JAFFE 372 et seq.; Vining, Direct Judicial Review and the Doctrine of Ripeness in Administrative Law, 69 MicH. L. REv. 1443 (1971); Note, Reviewability of Administrative Action: The Elusive Search for a Pragmatic Standard, 1974 DuKe L.J. 382; Note, The Judicial Role in Defining Procedural Requirements for Agency Rulemaking, 87 HARV. L. REv. 782 (1974).

54. 522 F.2d at 312, citing Armstrong v. Manzo, 380 U.S. 545, 552 (1965), and Goldberg v. Kelly, 397 U.S. 254 (1970).

55. The state review procedure is discussed in note 44 supra. The court recognized that there is a presumption that state courts will enforce federal constitutional guarantees. See Huffman v. Pursue, Ltd., 420 U.S. 592, 611 (1975). Following Huffrian, the court stated that federal judicial intervention is improper under most circumstances until a completed state action has been shown to have resolved a federal question inadequate1y. Id. at 606; 522 F.2d at 311-12 \& n.32. The court followed the Supreine Court's reasoning that "a party is not deprived of due process who, having no federal cause of action, is relegated to the state courts for redress." 522 F.2d at 313, citing Murdock v. City of Memphis, 87 U.S. (20 Wall.) 590, 632 (1875); Huffman v. Pursue, Ltd., 420 U.S. 592 (1975).

In support of its contentions, West Penn referred the court to its earlier decision in Duquesne Light Co. v. EPA, 481 F.2d 1 (3d Cir. 1973), modified, 522 F.2d 1186 
would have to bring suit in a federal court to enforce the state plan. Since the questions raised by West Penn would not have been initially reviewable, they presumably could be presented as defenses in an enforcement action. Therefore, there would be an opportumity for federal judicial review of West Penn's claims if the threat of federal penalty were ever to ripen into actuality. ${ }^{86}$

\section{An Analysis of West Penn and a Proposed FRAMEWORK FOR JUDICIAL REVIEW}

While the West Penn court achieved a defensible disposition of the particular dispute before it, its handling of the nnderlying issues on which the holding is based reflects the inadequacy of the analytical techniques now employed in dealing with the problem situations most commonly encountered in obtaining judicial review under the Amendments. The following discussion will focus imdividually on several of these problem areas in an attempt to develop a reasonable analytical approach and suggest a generally applicable framework for resolving questions of judicial reviewability under the Amendments.

(3d Cir. 1975). There, the plaintiff utility challenged the Pennsylvania implementation plan in a section $307(b)$ action, claiming inadequate opportunity to be heard in the state decision-making process. The Duquesne court agreed, and required EPA to remedy the procedural defects by conducting a limited legislative hearing itself or by staying federal enforcement procedures pending Duquesne's pursuit of more adequate state remedies. Id. at 10. The West Penn court distinguished its earlier decision, emphasizing that the Duquesne holding was based on an initial finding that the state hearing was inadequate. Id. at 9. As the West Penn court correctly asserted, Duquesne did not hold that relegation to a state remedy was per se violative of due process. But see Buckeye Power Co. v. EPA, 481 F.2d 162, 169-73 (6th Cir. 1973). See also Duquesne Light Co. v. EPA, 481 F.2d 1 (3d Cir. 1973), modified, S22 F.2d 1186 (3d Cir. 1975); Appalachian Power Co. v. EPA, 477 F.2d 495, 502-03 (4th Cir. 1973).

On the detailed procedural requirements for the various forms of hearings provided under the Amendinents, see South Terminal Corp. v. EPA, 504 F.2d 646 (1st Cir. 1974); Delaware Citizens for Clean Air, Inc. v. Administrator U.S. EPA, 480 F.2d 972 (3d Cir. 1973); International Harvester Co. v. Ruckelshaus, 478 F.2d 615 (D.C. Cir. 1973); Kennecott Copper Corp. v. EPA, 462 F.2d 846 (D.C. Cir. 1972). The general procedural requirements for administrative hearings are set forth at 5 U.S.C. $\$ \$ 553-57$ (1970). These statutes have been authoritatively construed in United States v. Allegheny-Ludlum Steel Corp., 406 U.S. 742 (1972), and United States v. Florida E. Coast Ry., 410 U.S. 224 (1973). Procedural requirenents are reviewed generally in Note, The Judicial Role in Defining Procedural Requirements for Agency Rulemaking, supra note 53.

56. West Penn also had a right to confer with the Administrator concerning the violation charged before enforcement could be undertaken. Amendinents $\$ 113(\mathrm{a})(4)$, 42 U.S.C. \& 1857c-8(a)(4) (1970). West Penn met with the Administrator, and was granted sixty-day extensions of the deadlines for initiating conpliance. The court characterized these conferences as "a second route to relief." 522 F.2d at 312 \& n.33. 


\section{Initial Court of Appeals Review}

In determining what issues are suitable for initial review of EPA approval of a state implementation plan, the courts must balance Congress's clear primary imtent of expediting improvement in air quality ${ }^{57}$ with its expressed sensitivity to the need for adequate judicial review of administrative action taken in pursuit of that goal. ${ }^{58}$ It must be remembered as well that preventing hitigation at an early stage in the process will not necessarily produce the most rapid changes in industrial practices, simce deferral of objections will necessarily prolong the enforcement process. ${ }^{59}$

There are two possible approaches to limiting the scope of initial review in the federal circuit courts. First, the courts inight put substantive limits on the subject matter of allowable objections which may be raised at this time. Specifically, the argument has been made that the plan and revision approval provisions of the Amendments should be construed to perimit the EPA to consider only the evaluative criteria enumerated in that provision in deciding whether to approve a particular state plan. ${ }^{60}$ The court reviewing EPA action on the plan, it is argued, should therefore be restricted to these same criteria in evaluating such action. The circuits are currently split on the issue, with resolution by the Supreme Court possible. ${ }^{81}$

57. See note 29 supra and accompanying text.

58. See, e.g., SENATE REPORT 40-41.

59. The West Penn litigation, for example, involved a state plan promulgated in January, 1972. The case was not resolved until July, 1975. See also Getty Oil Co. v. Ruckelshaus, 467 F.2d 349 (3d Cir. 1972), cert. denied, 409 U.S. 1125 (1973) (more than two years between issuance of state plan and end of litigation). See notes 6869 infra and accompanying text.

60. This construction would exclude from consideration questions of economic and technical feasibility. See note 61 infra.

61. The courts have been in conflict regarding whether the Administrator, and therefore the courts reviewing his determination, can consider only the criteria enumerated in sections $110(\mathrm{a})(2)(\mathrm{A})-(\mathrm{H}), 42$ U.S.C. $\$ \$ 1857 \mathrm{c}-\mathrm{a}(2)(\mathrm{A})-(\mathrm{H})(1970)$, in approving or disapproving a state plan or revision, or whether the scopo of the evaluation may be expanded to include such factors as economic and technological feasibility. The Third, Fourth, Sixth, and Ninth Circuits have found, in varying contexts, that economic and technological feasibility are legitimate concerns for the Administrator in evaluating a state plan. See St. Joe Mineral Corp. v. EPA, 508 F.2d 743, 747 (3d Cir. 1975), petition for cert. filed, 44 U.S.L.W. 3001 (U.S. June 28, 1975); Natural Resources Defense Council, Inc. v. EPA, 507 F.2d 905, 914 (9th Cir. 1974); Appalachian Power Co. v. EPA, 477 F.2d 495, 506 (4th Cir. 1973); Buckeye Power Co. v. EPA, 481 F.2d 162, 169 (6th Cir. 1973). The relevance of nonstatutory criteria to the Administrator's determination has been rejected by the Fifth, Seventh, and Eighth Circuits. See Texas v. EPA, 499 F.2d 289, 314-15 (5th Cir. 1974); Indiana \& Mich. Elec. Co. v. EPA, 509 F.2d 839, 843 (7th Cir. 1975); Union Elec. Co. v. EPA, 515 F.2d 206, 215-16 (8th Cir. 1975).

The nore convincing arguments have been nade by the Union Electric court, which 
Alternatively, or additionally, the courts might impose generic limitations on the types of objections permitted in initial review actions. In particular, objections to the general guidelines established by a state plan might be allowed at this time, while objections to the details of the plan's application to particular industries might not. In West Penn, the district court followed the more common practice ${ }^{62}$ of not making this distinction. ${ }^{03}$ The appellate court, however, attempted to impose sucli a generic restriction in rejecting the lower court's analysis and holding that a complaint concerning the specific application of a plan to a particular polluter was not an objection to that plan within the meaning of the initial review provision of the Amendinents. ${ }^{64}$

The specificity criterion proposed, although attractive by reason of its apparently broad applicability, is inherently unworkable. The West Penn court was inaccurate in its imitial assumption that the state plans intended for initial court of appeals review are very general documents. On the contrary, the plans must be highly specific with respect to inspection, regulation, and enforcement. ${ }^{05}$ It is difficult to see low a potentially affected industry could make a meaningful objection to a state plan without making reference to the specific provisions and applications threatening its interests.

The workability problem is reflected in the Third Circuit's own experience. For example, the court in West Penn failed to explain

supported its position with a wide-ranging review of expressions of congressional intent. See, e.g., Senate Report 2-3; 116 Cong. Rec. 32,900-05 (1970) (remarks of Senator Muskie). The court pointed out that other eourts had erroneously relied on the history of the House bill in discerning congressional intent, inisled by the fact that the Conference Committee had technically agreed on the House bill. The substance of the stronger Senate bill, however, was retained in the version which was finally enacted. Union Elec. Co. v. EPA, 515 F.2d 206, 215 \& n.30 (7th Cir. 1975). An example of erroneous judicial interpretation of the legislative history can be found in Buckeye Power Co. v. EPA, 481 F.2d 162, 168 (6th Cir. 1973).

Resolution of the question may be forthconning, as a petition for certiorari has been filed in the St. Joe Mineral case. Language used by the Court in Train v. Natural Resources Defense Council regarding the imperative force of the word "shall" suggests that its ruling may favor the Union Electric position:

$\$ 110$ (a) (3) requires the Agency to approve "any revision" which is consistent with 8110 (a) (2)'s minimum standards for an initial plan, and which the State adopted after reasonable public notice and hearing; no other restrictions whatsoever are plaeed on the Agency's duty to approve revisions. Train v. Natural Resources Defense Council, 421 U.S. 60, 98 (1975) (emphasis added) (footnote omitted).

See generally Bleicher, Economic and Technological Feasibility in Clean Air Act Enforcement Against Stationary Sources, 89 HARV. L. REV. 316 (1975).

62. See note 70 infra and accompanying text.

63. See note 47 supra.

64. 522 F.2d at 308-09.

65. See, for exainple, the dispute over the alleged lack of specificity in the New York plan in Friends of the Earth v, EPA, 499 F,2d 1118, 1123-24 (2d Cir. 1974). 
adequately the apparent conflict in its rulings on the specificity issue in that case and in Getty Oil Co. v. Ruckelshaus. ${ }^{68}$ Getty's claim, couched in terms of a general objection to the state plan, was found reviewable even though the Deleware regulations at issue were worded so specifically as to be applicable only to the Getty facility. ${ }^{67}$ Rather than providing useful guidance regarding what types of issues should be presented at what stages of the statutory process, the two cases taken together imply that the Third Circuit will be influenced most strongly by the phrasing of the pleadings in deciding this crucial question.

From a practical standpoint, it is wholly irrelevant whether the West Penn court was technically accurate in its attempted distinction of Getty. The problem lies in the very necessity of making distinctions as fine as that between an objection to a detail appearing on the face of a state plan and an objection to a detail arising out of the plan's application. Regardless of the logic of its position, the fact remains that twice in three years the Third Circuit has faced lengthy litigation in which a 'clarification of that position was sought. ${ }^{\text {s }}$ Such litigation can result only in delay and a frustration of Congress's purpose in enacting the Amendments. ${ }^{6 \theta}$

There have been no cases directly on this point in the other circuits. It may be significant that specificity as bearing on initial reviewability was not discussed in a number of similar cases where review was granted to litigants who were obviously concerned only with the application of the details of a state plan to their own facilities. ${ }^{70}$ No other court has rejected an objection presented for initial review as overly specific. Further, the Supreme Court's refusal in its recent decision in Train $v$ Natural Resources Defense Council, Inc. ${ }^{71}$ to distinguish "postponements" from "variances" or "revisions" on the basis of specificity is

66. 467 F.2d 349 (3d Cir. 1972), cert. denied, 409 U.S. 1125 (1973). The case is discussed in note 47 supra.

67. Id. at 353:

[T] limiting the amount of sulphur content of fuel burned in New Castle County south of United States Route 40 by fuel burning equipment having a maximum rate of heat input equal to or greater than $50,000,000$ b.t.u. per hour to $3.5 \%$. The Delmarva power station is the only installation presently operating such equipinent in the area.

68. See note 59 supra.

69. See note 29 supra and accompanying text.

70. See, e.g., St. Joe Minerals Corp. v. EPA, 508 F.2d 743 (3d Cir. 1975); South Terminal Corp. v. EPA, 504 F.2d 646 (1st Cir. 1974) (review of EPA plans proinulgated in default of state plan); Anaconda Co. v. Ruckelshaus, 482 F.2d 1301, 1303 (10th Cir. 1973) (implying that specific objection would have been reviewable if properly made in section 307 (b) action).

71. 421 U.S. 60, 97-98 (1975). The case is discussed in note 15 supra. 
collateral evidence that so unworkable a standard will be found generally unacceptable.

Once the Supreme Court has resolved the issue of subject matter limitations on initial review, ${ }^{72}$ the courts should reject the imposition of any generic criteria beyond that of reasonable foreseeability. ${ }^{73}$ Affected industries should be required to make any objections which are reasonably foreseeable at the time of EPA approval in the court of appeals at that time. Objections found in subsequent federal proceedings to have been initially foreseeable should not be heard. ${ }^{74}$

Using a foreseeability criterion, the objections raised in both West Penn and Getty would have been found suitable for initial review in the court of appeals, with later review thus foreclosed. In each case, the affected industry was able to develop its objection to the state plan at the time of promulgation. ${ }^{75}$ Since the grounds for objection were foreseeable, the factors cited by the West Penn court in distinguishing Getty would have been irrelevant under this test. ${ }^{76}$

Consider, by way of contrast, the situation of an industry subject to a state plan which affects its present operations as well as prospective modifications of those operations. If such an industry were to raise a general objection to the plan at some time after promulgation when the substance of its objection became more defined, a court using the West Penn analysis inight refuse review on the grounds that any objection to the general provisions of a plan can be heard only in an initial court of appeals proceeding. ${ }^{77}$ Under a foreseeability standard, however, the

72. See note 61 supra.

73. For a discussion of the legal concept of foreseeability in the context of tort law, see W. Prosser, HANDboor of the LAW of ToRTs 250-70 (4th ed. 1971). The criterion of foreseeability proposed here is analytically the same as that used in determining tort liability.

74. Seo notes 20-21 supra and accompanying text. The foreseeability criterion should also be employed in construing the exception to the foreclosure provision for objections arising after the thirty-day period for initial review has expired. Amendments s 307(b)(1), 42 U.S.C.A. $\$ 185711-5$ (b)(1) (Supp. 1976). An objection would be held to lave arisen after the thirty-day period if it could not have been foreseen within that period. Cf. Oljato Chapter of the INavajo Tribe v. Train, 515 F.2d 654, 665 (D.C. Cir. 1975) (reflecting the difficulties of determining precisely when the grounds for an objection have arisen).

75. In West Penn, the utility was able to develop its objection in the form of a state variance request shortly after EPA approval of the Pennsylvania plan. 522 F.2d at 305. A state variance was also promptly applied for in Getty. 467 F.2d at 353.

76. Sec notes 66-67 supra and accompanying text.

77. Since its objection was in fact to the terms of the original plan, an industry in this position could not rely wholly on its ability to invoke the statutory exception to foreclosure for objections based on grounds arising solely after the thirty-day period for initial review. See note 74 supra. 
industry might argue successfully that the scope of its objection was not sufficiently foreseeable to have been meaningfully litigated mitially. An industry in such a position would therefore lold its objection until it could be fully aired in a single dispositive action, rather than bringing a series of inconclusive and time-consuming actions out of fear of foreclosure. ${ }^{78}$

The adoption of sucl a standard would, of course, result in additional cases coming before the court of appeals for mitial review. Court time, however, would seein better devoted to substantive determinations than to the type of unproductive legal wrangling exemplified by West Penn. Substituting a widely accepted legal concept for the chimerical notion of specificity could not help but simplify the judicial review process, with an overall result of greater accommodation to Congress's primary concerns.

\section{Subsequent Review of Issues Not Initially Reviewable}

In light of the congressional policy against the use of litigation as a delaying tactic, ${ }^{78}$ the final enforcement proceeding should be the primary forum for raising issues not earlier foreclosed. In principle, there are no limits to the form or substance of the defenses which can be asserted in an enforceinent action. ${ }^{80}$ As West Penn illustrates, however, situations will arise in which due process will require judicial review of administrative action which falls short of actual enforcement.

As the West Penn court accurately observed, "due process is protean, its actual form at any time being a function of the rights and interests at stake in a given proceeding." and interests" at stake in West Penn, the court's application of the standard thus articulated in concluding that the utility had had and would have opportunities for "meaningful" hearings at "meaningful" times is unacceptable. ${ }^{82}$

First, although a state proceeding is not per se an inadequate ineans of vindicating federal rights, ${ }^{83}$ it does not appear that the administrative and judicial proceedings which West Penn had initiated were capable of providing it with adequate protection froin allegedly unrea-

78. See note 59 supra and accompanying text.

79. See notes 29-30 supra and accompanying text.

80. See note 37 supra.

81. 522 F.2d at 312 n.35, citing Mitchell v. W.T. Grant Co., 416 U.S. 600,610 (1974).

82. See notes 54-55 supra and cases cited therein.

83. See note 55 supra. 
sonable EPA action. Any state modification of the plan to accommodate West Penn would be imeffective without EPA approval. ${ }^{84}$ Such state action could therefore have no impact on an EPA determination to cite West Penn for a violation of the plan. ${ }^{85}$ The agency would be acting pursuant to an imdependent federal statutory duty, and, considering the purposes of joint state-federal enforcement, it would not appear to be bound by state action. ${ }^{86}$

Second, the notion that an enforcement proceeding would provide a meaningful opportunity to review the EPA's issuance of a violation notice is illusory. ${ }^{87}$ The reviewability of the notice itself is premised on its effect in setting a time from which penalties may accumulate. But the timing of the enforceinent proceeding, and therefore the period during which daily fines may accrue, is entirely in the hands of the agency. ${ }^{88}$ To rely on this form of review in a factual context similar to that in West Penn would be effectively to give the agency absolute control over the extent of the penalty which might be imposed. ${ }^{89}$ Thus,

84. See notes 14-19 supra and accompanying text.

85. See notes 16-19 supra and accompanying text.

86. See Senate Report 21: "If the Secretary ['Administrator" in the final version] should find that a state or local pollution control agency is not acting to abate violations of implementation plans or to enforce certification requirements, he would be expected to use the full force of Federal law." A state administrative or judicial construction of a plan which the Administrator found to be overly lenient would seem to provide exactly the kind of situation in which Congress intended him to exercise his independent enforcement authority. In light of this expression of clear congressional intent, it is likely that state determinations on the validity of variances or revisions would be held to have no binding effect on a federal court in an enforcement proceeding.

87. 522 F.2d at 319 (Adams, J., dissenting).

88. See notes 17-19 supra and accompanying text. Note that there is no apparent outside restriction on the time within which enforcement proceedings must be initiated. Fines would presumably continue to accumulate pending final enforcement.

89. It should be emphasized that, despite the comparability of eertain aspects of the two cases, West Penn's problem was not the so-called "Getty dilemma." Duquesne Light Co. v. EPA, 481 F.2d 1, 7-8 (3d Cir. 1973); Getty Oil Co. v. Ruckelshaus, 467 F.2d 349 (3d Cir. 1972), cert. denied, 409 U.S. 1125 (1973). In Getty, the plaintiff chose to pursue a state remedy in place of federal court of appeals review. The Getty court held correctly that Congress's intent was clear that the decision not to seek federal review when available could not be used to defeat or delay federal enforcement. See also Train v. Natural Resources Defense Council, 421 U.S. 60, 92 (1975): "This litigation [over variances, referring to Getty] is carried out on the polluter's time, not the public's for during its pendency the original regulations remain in effect, and the polluter's failure to comply may subject him to a variety of enforcement procedures." In West Penn, however, the court held not that the polluter had neglected his federal remedy for purposes of delay, but that he had not had a right to such a remedy. West Penn was therefore in the very different position of being subject to a federal determination having substantial impact on it without ever having had. an opportunity for meaningful federal review. 
close analysis of the options available to West Penn reveals that the company had no real opportunity for a "meaningful" hearing on its claims.

But, even where the need for intermediate judicial review can be shown, the question of a jurisdictional base renains. In determining the feasibility of any approach to the jurisdiction problem, two related questions nuust be answered: first, whether the base claimed actually constitutes an affirmative grant of jurisdiction; and second, whether the facts presented are likely to be found ripe for review.

Within the Amendments theniselves, the citizen suit provision is the only arguable source of jurisdiction for intermediate federal review. ${ }^{90}$ Unfortunately, West Penn provides little guidance on the question, since the court rejected citizen suit jurisdiction on procedural grounds without comment on the general applicability of the provision to this type of situation..$^{21}$ As noted earlier, the inanifest purpose of the provision is to provide a public check on EPA vigilance. ${ }^{92}$ Recent Suprene Court dicta on the nature of administrative discretion under the Amendments suggest, however, that West Penn night have successfully invoked the provision if it had followed the proper notice procedure and had directed its complaint toward EPA's refusal to approve the state variance it was ultimately granted ${ }^{93}$ Since the revision approval provision states that the agency "shall approve" a revision of a state plan meeting enumerated criteria ${ }^{94}$ West Penn, had it claimed that Pennsylvania was revising its plan by granting the variance, might have received a court hearing on the EPA's alleged failure to perform its non-discretionary duty of plan revision approval. ${ }^{95}$

90. Amendments $\S 304,42$ U.S.C. $\$ 1857 \mathrm{~h}-2$ (1970) (quoted in part in note 22 supra).

91. 522 F.2d at $307 \&$ n. 20 . See note 47 supra.

92. See notes 22-23 supra and accompanying text.

93. See Train v. Natural Resources Defense Council, 421 U.S. 60, 80, 98 (1975). Although the term "non-discretionary" was not used, the Court found that the words "shall approve" in the plan revision section "required" the Administrator to approve a revision meeting the statutory criteria.

94. Amendments § 110(a)(3)(A), 42 U.S.C.A. § 1857c-5(a)(3)(A) (Supp. 1976).

95. West Penn would assert, in other words, that the Supreme Court's use of the word "required" in Train necessarily implied a non-discretionary duty of the Administrator to approve its request for a variance if it did not result in the Pennsylvania plan being revised in contravention of the minimal statuory criteria. See note 14 supra and accompanying text. A court taking review jurisdiction under the citizen suit provision would presumably go on to evaluate the proposed variance in terms of those criteria, specified in Amendments $\S \S 110(a)(2)(A)-(H), 42$ U.S.C.A. $\S \S 1857 c-5(a)(2)(A)-$ (H) (Supp. 1976).

Having taken jurisdiction, the federal court could then have exercised pendent jurisdiction to explore the legally and factually related questions of West Penn's present 
The use of the citizen suit provision to obtain jurisdiction in this situation is admittedly an artificial device. While a particular industry may technically qualify to bring suit under the provision, it is actually seeking review in its capacity as an industry adversely affected by EPA action under the Amendments rather than in its capacity as a "person" policing EPA laxity in enforcement. Nonetheless, it is a device which will accomplish a legitinate purpose. Implicit in the West Penn opinion is the constant conflict between the court's desire to follow Congress's intent exactly and its concern that the needs of due process and basic equality be inet. The court seemed to be sensitive to the cogency of the argument for review, but refused to stretch the statute beyond its literal terms in finding the necessary jurisdictional grant. ${ }^{96}$ Invoking citizen suit jurisdiction in the manner suggested would allow a court to follow its equitable leanings without violating the terms of the Amendinents in cases where the needs of both the affected industry and the environment would be best served by prompt judicial resolution of a critical question.

The Administrative Procedure Act ${ }^{97}$ is a second possible source of jurisdiction for intermediate judicial review. The West Penn court, relying without supporting reasonimg on a series of prior Third Circuit decisions, held that the APA did not confer jurisdiction, but inerely specified the procedure for review where a case was otherwise within a federal court's jurisdiction. ${ }^{98}$ However, while this holding accords with the interpretation adopted by several other circuits, ${ }^{99}$ there has been

and prospective violation of the state plan. United Mine Workers v. Gibbs, 383 U.S. 715 (1966). Potential claims of eleventh amendment immunity by state officials have been circumvented by courts applying conparably integrated state-federal statutory schemes. See River v. Richmond Metropolitan Authority, 359 F. Supp. 611 (E.D. Va.), aff'd, 481 F.2d 1280 (4th Cir. 1973); Connecticut Union of Welfare Employees v. White, 357 F. Supp. 1378 (D. Conn. 1973). This jurisdictional alternative has been previously suggested in Luneburg \& Roselle, Judicial Review Under the Clean Air Amendments of 1970, 15 B.C. IND. \& CoM. L. REv. 667, 691 n.145 (1974).

96. The conflict was expressed more explicitly by the lower court. Compare 378 F. Supp. at 945 with 378 F. Supp. at $946-47$.

97. 5 U.S.C. $\S \S 701-06$ (1970).

98. 522 F.2d at 309-11 \& n.29; see PBW Stock Exchange, Inc. v. SEC, 485 F.2d 718, 729 (3d Cir. 1973); Getty Oil Co. v. Ruckelshaus, 467 F.2d 349, 356 (3d Cir. 1972), cert. denied, 409 U.S. 1125 (1973); Zimmerman v. United States Gov't, 422 F.2d 326, 330 (3d Cir.), cert. denied, 399 U.S. 911 (1970). The court put special emphasis on the Suprenie Court's "favorable citation" of Getty in Train. 522 F.2d at 310 n.29. The Suprene Court, however, cited Getty on an unrelated point. Train v. Natural Resources Defense Council, 421 U.S. 60, 92 (1975).

99. For cases holding that the APA does not afford a basis for jurisdiction, see Bramblett v. Desobry, 490 F.2d 405, 407 (6th Cir.), cert. denied, 419 U.S. 872 (1974); Getty Oil Co. v. Ruckelshaus, 467 F.2d 349, 356 (3d Cir. 1972), cert. denied, 409 U.S. 1125 (1973); Arizona State Dep't of Pub. Welfare v. Department of HEW, 449 F.2d 
no definitive Supreme Court ruling on the question, and there is conflicting authority both among and within the circuits. ${ }^{100}$ Thus, the availability at present of the APA as a jurisdictional basis will depend upon the circuit in which the action is brought.

456, 464 (9th Cir. 1971), cert. denied, 405 U.S. 919 (1972); Pan Am. World Airways v. CAB, 392 F.2d 483, 494 (D.C. Cir. 1968); Ove Gustavsson Contracting Co. v. Fioete, 278 F.2d 912, 914 (2d Cir.), cert. denied, 364 U.S. 894 (1960).

100. A number of courts taking the opposite position have stated it in absolute terms, failing even to suggest the necessity of dealing with the contrary view: "Jurisdiction over the United States defendants for the federal statutory clains . . . is conferred by the Administrative Procedure Act . . . ." River v. Richmond Metropolitan Authority, 359 F. Supp. 611, 622 (E.D. Va.), aff'd, 481 F.2d 1280 (4th Cir. 1973) (empliasis added). Other cases which rely on the APA as a grant of jurisdiction include Oljato Cliapter of the Navajo Tribe v. Train, 515 F.2d 654, 663-64 (D.C. Cir. 1975) (dicta); Elton Orchards, Inc. v. Brennan, 508 F.2d 493, 497 (1st Cir. 1974); Pickus v. United States Bd. of Parole, 507 F.2d 1107, 1110 (D.C. Cir. 1974); Albert v. Cliafee, 465 F.2d 367, 368 (9th Cir. 1972).

The Court of Appeals for the Second Circuit has taken almost every conceivable position on tle subject:

In various decisions, the [jurisdictional] sufficiency of the A.P.A. has been explicitly uplield, Citizens Committee for Hudson Valley v. Volpe, 425 F.2d 97,102 (2d Cir.), cert. denied, 400 U.S. $949 \ldots$ (1970), explicitly stated by Judge Lumbard in a concurring opinion, Rosado v. Wyman, 414 F.2d 170, 181 (2d Cir. 1969), rev'd on other grounds, 397 U.S. $397 \ldots$ (1970), assumed, Cappadora v. Celebrezze, 356 F.2d 1, 5-6 (2d Cir. 1966), doubted, Wolff v. Selective Service Board, 372 F.2d 817, 826 (2d Cir. 1967), and, most recently, said to be an open question, Aguayo v. Ricliardson, 473 F.2d 1090 (2d Cir. 1973) [cert. denied, 414 U.S. 1146 (1974)]. Connecticut Union of Welfare Employees v. White, 357 F. Supp. 1378, 1379 (D. Conn. 1973) (uploolding jurisdiction).

As evidence of a strong overall presumption in favor of reviewability, the courts favoring APA jurisdiction have relied on the legislative history of the Act, see, e.g., H.R. REP. No. 1980, 79th Cong., 2d Sess. 41 (1946); S. REP. No. 752, 79th Cong., 1st Sess. 26 (1945); the collaterally relevant Supreme Court lioldings, see Citizens to Preserve Overton Park, Inc. v. Volpe, 401 U.S. 402 (1971); Abbott Laboratories v. Gardner, 387 U.S. 136 (1967); Toilet Goods Ass'n v. Gardner, 387 U.S. 158 (1967); Rusk v. Cort, 369 U.S. 367 (1962); Frozen Foods Express v. Uurited States, 351 U.S. 40 (1956); United States v. Storer Broadcasting Co., 351 U.S. 192 (1956); and the common law trends underlying the APA, see 4 DAvis $\S \S 28.01-.07$; JAFFE 320-94. These courts lave inferred, in light of this presumption, that an expansive view properly governs the deternination of jurisdietion. Contrary arguments have been premised on the general philosophy that federal courts should not grope for jurisdiction where an explicit statutory grant is lacking, see cases cited in note 98 supra, and the language of the APA. See, e.g., 5 U.S.C. $\$ 703$ (1970), which refers to an "action . . . in a court of competent jurisdiction," suggesting that an independent jurisdictional base is necessary. But see 4 DAvis \& 28.08. Professor Davis argues that a presumption of reviewability arises unequivocally from the face of the statute and that no construction is necessary. See, e.g., 5 U.S.C. $\$ 702$ (1970): "A person suffering legal wrong because of agency action . . . is entitled to judicial review ...."

Part of the problem may lie in the courts' frequent confusion of the related and often overlapping, but still logically separate, concepts of jurisdiction and ripeness. In purporting to discuss the presence or absence of a jurisdictional grant, many courts have, for example, evaluated the relative finality of the agency action, althougl this point bears 
It would appear as well that a federal court could assume jurisdiction over a suit like West Perm's pursuant to either the general federal question statute ${ }^{101}$ or the commerce-related federal question statute. ${ }^{102}$ In general terms, these statutes afford a basis for jurisdiction when a particular cause of action "arises under" federal law. In the case of a general federal question, there is an additional requirement that the amount in controversy exceed $\$ 10,000 .{ }^{103}$ While a similar jurisdictional amount is not required for commerce-related jurisdiction, the federal law involved in this instance must be one "regulating commerce."104

In West Penn, the EPA, acting pursuant to the mandate of a federal law bearing on interstate commerce, issued a notice of violation of a state plan which the agency's approval had effectively incorporated into federal law. In terms of either prospective fines or cost of coinpliance, West Penn clearly lad more than $\$ 10,000$ at stake. Thus, jurisdiction arguably could have been founded on either federal question jurisdiction statute. The court recognized that such jurisdiction might have been proper, but chose not to inake such a determination on its own imitiative. ${ }^{105}$ There is no direct authority to support such jurisdiction, but two federal district courts lave held that the commerce-related

only on the ripeness of the problem for judicial review. See, e.g., National Ethical Pharmaceutical Ass'n v. Weinberger, 503 F.2d 1051, 1052 (4th Cir. 1974); Independent Bankers Ass'n v. Board of Governors of Fed. Reserve Sys., 500 F.2d 812, 814 (D.C. Cir. 1974). See generally JAFFE 395-423; Cramton, Nonstatutory Review of Federal Administrative Action: The Need for Statutory Reform of Sovereign Immunity, Subject Matter Jurisdiction, and Parties Defendant, 63 MrcH. L. REv. 387, 443-46 (1970).

In West Penn, the majority and the dissent argued past each other on the question of "jurisdiction." The majority pointed out preliminarily that there was no affirmative grant of jurisdiction to bring the case within the general competence of the federal court. 522 F.2d at 313-14. The dissent purported to answer this contention by arguing that the case met the established ripeness criteria for review of administrative action. Id. at 317-20. This argument, of course, did nothing more than assume the invalidity of the majority's basic premise, that affirmative jurisdiction was lacking.

101. "The district courts shall have original jurisdiction of all civil actions wherein the matter in controversy exceeds the sum or value of $\$ 10,000 \ldots$ and arises under the Constitution, laws, or treaties of the United States." 28 U.S.C. $\$ 1331$ (a) (1970).

102. "The district courts shall have original jurisdiction of any civil action or proceeding arising under any Act of Congress regulating commerce or protecting trade and commerce against restraints and monopolies." Id. § 1337. See Dunlop v. Bachowski, 421 U.S. 560, 566 (1975).

103. 28 U.S.C. $\$ 1331$ (a) (1970).

104. Id. $\$ 1337$.

105. 522 F.2d at $308 \&$ n.26. In reaching decisions, federal courts, of course, are not limited to rationales urged on them by the parties. Mapp v. Ohio, 367 U.S. 643 (1961) is a famous example of an important case which was decided on a point not briefed or argued by the parties. The court apparently did not act here because of its belief that the question was not ripe for review in any event. 
federal question statute would provide a jurisdictional basis for suits brought under the National Environmental Policy Act (NEPA). ${ }^{106}$

The secondary problem of whether an intermediate EPA action is sufficiently final to be ripe for review is illustrated by the conflict within the West Penn court itself. Evaluating the facts before it in light of the apposite Supreme Court decisions, the court found that the mere issuance of a violation notice was without substantial coercive effect, ${ }^{10} \mathrm{i}$ was neither formal, definitive, nor self-executing in its impact, ${ }^{108}$ and hence was not ripe for review. As the dissent correctly pointed out, however, the majority took an overly technical view of the concept of finality. The tenor of the pertinent Supreme Court holdings is that finality is to be determined by balancing the practical impact of the agency action on the affected parties against the threat of disruption of the administrative process, all viewed from the perspective of a strong presumption of reviewability. ${ }^{109}$

By any reasonable standard of practicality, the impact on West Penn of the EPA's issuance of a violation notice was final and substantial. Since the timing of the notice would determine the scope of any penalty imposed, ${ }^{110}$ West Penn was confronted with the choice of ignor$\mathrm{mg}$ the notice in reliance on its belief that it was innocent of any violation, with the possibility of having daily fines assessed from that

106. Natural Resources Defense Council v. SEC, 389 F. Supp. 684 (D.D.C. 1974); Citizens for Clean Air, Inc. v. Corps of Eng'rs, U.S. Army, 349 F. Supp. 696 (S.D.N.Y. 1972).

107. 522 F.2d at 311, citing Columbia Broadcasting Sys. v. United States, 316 U.S. 407, 418 (1942).

108. 522 F.2d at 311, citing Abbott Laboratories v. Gardner, 387 U.S. 136, 151 (1967); Toilet Goods Ass'n v. Gardner, 387 U.S. 158, 162, 171 (1967).

109. See Abbott Laboratories v. Gardner, 387 U.S. 136 (1967):

The cases dealing with judicial review of administrative action have interpreted the "finality" element in a pragmatic way .... ....

This is also a case in which the impact of the regulations upon the petitioners is sufficiently direct and immediate as to render the issue appropriate for judicial review at this stage. Id. at 149,152 .

See also United States v. Storer Broadcasting Co., 351 U.S. 192, 198 (1956); Frozen Food Express v. United States, 351 U.S. 40, $43-45$ (1956); Columbia Broadcasting Sys. v. United States, 316 U.S. 407, 418-19 (1942).

The Court has subsequently restated its pragmatic emphasis in a more explicit formula: "[T]he relevant considerations in determining finahity are whether the process of administrative decisionmaking has reached a stage where judicial review will not disrupt the orderly process of adjudication and whether rights or obligations have been determined . . . ." Port of Boston Marine Terminal Ass'n v. Rederiaktiebolaget Transatlantic, 400 U.S. 62, 71 (1970).

110. See notes 17-19, 88 supra and accompanying text. 
point should a court later find against it, or undertaking the inevitably expensive process of coinphance. ${ }^{111}$

Administrative functioning would not appear to be seriously threatened by allowing review in such circumstances. The issue of whether the EPA had been correct in finding West Penn in violation of the state plan would ultimately have to be hitigated in an enforcennent proceeding in any event. The implicit basis of West Penn's claim was that the agency, by failing to imitiate enforcement proceedings immediately, had delayed this required judicial interpretation of the plan in derogation of its interests.

Finally, an action which is ripe may still be held unreviewable if it is cornmitted to the discretion of the agency in question, since the court would then have no objective standards to apply. ${ }^{112}$ In finding a commitment to agency discretion in West Penn, the court relied on the fact that the EPA would have discretion in choosing the mode of enforcement. The court noted that the violation notice provision of the Amendinents is worded imperatively, but that im taking further action the agency has two options, either of which it "may" pursue. ${ }^{113}$ The court einphasized that there is no explicit statutory language controlling if or when the agency must imitiate enforcement.

It was the non-discretionary issuance of a violation notice, however, and not the prospective enforcement action which was the subject of the review sought in West Penn. The original violation notice would similarly be the source of the threat to other affected industries fimding themselves in West Penn's position and seeking intermediate judicial review. Surely the existence or non-existence of a violation of a highly specific state plan is susceptible of objective determination. The mere presence of an element of discretion at a later stage of the process should not defeat reviewability when there are workable standards to apply. ${ }^{114}$

111. West Penn claimed that installation of a scrubber would cost $\$ 23$ million, and that its operation would add $\$ 6.5$ million to annual expenses. 522 F.2d at 318 n.30 (Adams, J., dissenting).

112. 5 U.S.C. $\$ 701(a)(2)(1970)$. See note 53 supra.

113. Whenever, on the basis of any information available to him, the Administrator finds that any person is in violation of any requirement of an applicable miplementation plan, the Administrator shall notify the person in violation of the plan .... If such violation extends beyond the 30th day after the date of the Administrator's notification, the Administrator may issue an order reguiring such person to comply with the requirements of such plan or he may bring a civil action in accordance with subsection (b) of this section. Amendments $\S 113(a)(1), 42$ U.S.C. $\$ 1857 c-8(a)(1)$ (1970) (empliasis added).

114. Congress intended, and the courts have consistently held, that the discretion exception is to be very narrowly applied. See Citizens to Preserve Overton Park, Inc. v. Volpe, 401 U.S. 402, 410 (1971); S. REP. No. 752, 79th Cong., 1st Sess. 26 (1945). The presence of any workable legal standard is usually enough to defeat the exception. 


\section{CONCLUSION}

In conclusion, it is urged that the courts adopt a consistent policy toward judicial review under the Clean Air Amendments. In doing so, the judiciary would aid industries subject to the Amendinents in understandimg, ineeting, and where appropriate, challenging their obligations, without impairing the spirit or functioning of the law..$^{115}$

As a first step, the courts must define the scope of the issues suitable for initial review in the court of appeals. The court's atteinpt in West Penn to establislı a criterion of specificity should be rejected. All objections, specific or general, to state plans and revisions or their application which are reasonably foreseeable at the time of promulgation slrould be committed to exclusive review under the initial review provision. In deciding whether to impose substantive restrictions on the subject matter of initial review proceedings, the lower courts will, of course, follow any Supreme Court determination of whether the EPA's action in evaluating plans and revisions is to be guided solely by the enumerated minimum plan requirements. ${ }^{116}$ Any. coin-

See, e.g., East Oakland-Fruitvale Planning Council v. Rumsfeld, 471 F.2d 524, 534 (9th Cir. 1972); Scanwell Laboratories, Inc. v. Shaffer, 424 F.2d 859, 864 (D.C. Cir. 1970). The language of the APA virtually compels such a construction. If the presence of any element of discretion were enough to preclude review under the discretion exception, 5 U.S.C. $\$ 701(\mathrm{a})(2)$ (1970), then 5 U.S.C. $\$ 706(2)(A)$ (1970), allowing agency action to be set aside for "abuse of discretion," would be rendered meaningless. See generally 4 DAvis § 28.16; JAFFE 359-63.

When all other preliminary questions have been resolved, the issue of the sovereign immunity of the United States Government remains. See generally Cramton, supra note 100, at 396-436. It has most often been held that a finding of reviewability under the APA will not in itself overcome the problem of sovereign immunity, but this approach has been criticized by the commentators almost without exception. See, e.g., Byse, Proposed Reforms in Federal "Nonstatutory" Judicial Review: Sovereign Immunity, Indispensable Parties, Mandamus, 75 Harv. L. Rev. 1479 (1962); Cramton, supra note 100 , at 417-36, 417 n.143. See generally 3 DAvis ch. 27; JAFFE 197-98, 213-31, 229 n.123. It is arguable that the various judicial review provisions of the Amendinents, especially the citizen suit provision, imply a general waiver of sovereign immunity with respect to suits arising from administration of the Amendments. But see Kentucky ex rel. Hancock v. Ruckelshaus, 497 F.2d 1172, 1176 (6th Cir. 1974), cert. granted sub nom. Hancock v. Train, 420 U.S. 971 (1975) (holding sovereign immunity was not waived except to the limited extent that the Amendinents specifically granted review). The problem of sovereign immunity as a bar to suits does not seem to have been considered by Congress in its deliberations on the Amendments.

115. A number of pre-Train articles have urged various courses of policy on courts conducting judicial review under the Amendments. See, e.g., Luneberg, supra note 16; Luneburg \& Roselle, supra note 95 at 671-93; Comment, Coordinating the EPA, NEPA, and the Clean Air Act, supra note 23, at 550-57; Comment, Variance Procedures Under the Clean Air Act, supra note 2.

116. See note 61 supra. 
plaints regarding unlawful administrative action which are not initially cognizable should be heard as defenses in statutory enforcement actions brought by the agency.

In certain fact situations, due process and considerations of fairness may impose a further requirement of federal judicial review of intermediate EPA action falling short of enforcement but having the practical impact of finality. Where these considerations apply, the federal courts should be able to derive an adequate jurisdictional grant from one of three sources: the Admimistrative Procedure Act, the general and commerce-related federal question statutes, or, where the complaint takes the form of an objection to EPA refusal to approve a state plan revision in the plaintiff's favor, the citizen suit provision of the Amendments.

The decisions to be made must be guided by constant reference to Congress's primary concern in enacting the Amendments, that of expediting a significant reduction in air pollution. Public liealth and welfare were given clear priority over considerations of economics and convenience. ${ }^{117}$ At the same time, it must be remembered that Congress expressed a complementary sensitivity to the established principles of judicial control over administrative action. ${ }^{118}$

117. See note 29 supra and accompanying text.

118. Seo Senate Report 40-41. 